\title{
Reidentification of Thiobacillus perometabolis ATCC 27793 and Thiobacillus sp. Strain A2 with Reference to a New Species, Thiobacillus rapidicrescens sp. nov.
}

\author{
YOKO KATAYAMA-FUJIMURA, ICHIRO KAWASHIMA, NAOKO TSUZAKI, AND HIROSHI \\ KURAISHI* \\ Faculty of Agriculture, Tokyo University of Agriculture and Technology, 3-Saiwaicho, Fuchu, Tokyo 183, \\ Japan
}

\begin{abstract}
Thiobacillus perometabolis THI $024(=$ ATCC 27793$)$ is closely related to Thiobacillus sp. strain $\mathrm{A}^{\mathrm{T}}$ (type strain) $\left(=\right.$ THI $041^{\mathrm{T}}=$ ATCC $25364^{\mathrm{T}}$ ), and these strains clearly differ from the known Thiobacillus species in their morphological and physiological characteristics, ubiquinone systems, deoxyribonucleic acid guanine-plus-cytosine contents, and cellular fatty acid compositions. We propose the name Thiobacillus rapidicrescens sp. nov. for these organisms. Strain THI 041 is the type strain of this species.
\end{abstract}

Thiobacillus sp. strain $\mathrm{A}^{\mathrm{T}}$ (type strain) has been investigated mainly with respect to its facultatively chemolithotrophic characteristics $(2,7,12,18)$; however, this strain has not been correctly identified since the isolation of the organism was reported by Taylor and Hoare in 1969 (14). In the course of our taxonomic studies on Thiobacillus species, we found that there is a close relationship between Thiobacillus sp. strain $\mathrm{A} 2^{\mathrm{T}}\left(=\right.$ THI $041^{\mathrm{T}}=$ ATCC $\left.25364^{\mathrm{T}}\right)$ and Thiobacillus perometabolis THI $022(=$ ATCC 27793) (5).

In a previous paper (5), we classified Thiobacillus species into three groups according to the ubiquinone systems in their respiratory chains, their cellular fatty acid compositions, and the guanine-plus-cytosine $(\mathrm{G}+\mathrm{C})$ contents of their deoxyribonucleic acids. In this classification scheme Thiobacillus $\mathrm{sp}$. strain $\mathrm{A}^{\mathrm{T}}$ was a member of group I, which included facultatively chemolithotrophic Thiobacillus species with ubiquinone 10 ; this group also contained $T$. perometabolis THI 022 and Thiobacillus novellus THI $031^{\mathrm{T}}$ (group I-1). These organisms had octadecenoic acid plus cyclopropane acid of $\mathrm{C}_{19}$ as their major non-hydroxylated cellular fatty acids, 3-hydroxydecanoic acid as a hydroxylated fatty acid, and $\mathrm{G}+\mathrm{C}$ contents of 67.0 to 67.8 mol\%. (Hexadecenoic acid and cyclopropane acid of $\mathrm{C}_{17}$ are presented together in our study [5], as are octadecenoic acid and cyclopropane acid of $\mathrm{C}_{19}$.) No hydroxylated fatty acid was detected in $T$. novellus $\mathrm{THI} 031^{\mathrm{T}}$. In contrast, $T$. perometabolis type strain THI 023 (= ATCC 23370) (8) was a member of group II, which included facultatively chemolithotrophic Thiobacillus species with ubiquinone 8 . This organism had hexadecanoic acid, hexadecenoic acid plus cyclopropane acid of $\mathrm{C}_{17}$, and octadecenoic acid plus cyclopropane acid of $\mathrm{C}_{19}$ as its major non-hydroxylated cellular fatty acids, 3-hydroxydecanoic acid and 3-hydroxydodecanoic acid as hydroxylated fatty acids, and a $\mathrm{G}+\mathrm{C}$ content of $65.0 \mathrm{~mol} \%$.

We identified some physiological characteristics of $T$. perometabolis THI 022 which clearly differed from the characteristics given in the original description (10). Therefore, we obtained the culture deposited with the American Type Culture Collection, Rockville, Md., under accession number ATCC 27793 to confirm the results described above, and we designated this organism $T$. perometabolis THI 024 for this study.

In this paper we present a detailed comparison of cultures and propose a new species, Thiobacillus rapidicrescens, for $T$. perometabolis strain THI 024 and Thiobacillus sp. strain $\mathrm{A} 2^{\mathrm{T}}$.

\section{MATERIALS AND METHODS}

Bacterial strains. The bacterial strains used in this study are listed in Table 1 . The group I Thiobacillus strains were maintained on BY agar slants and transferred once a month. T. perometabolis THI $023^{\mathrm{T}}$ was maintained on SM basal salts medium ( $\mathrm{pH} 6.0$ ) supplemented with $5 \%$ (wt/vol) sodium thiosulfate and $5 \%$ (wt/vol) yeast extract (Difco Laboratories, Detroit, Mich.) and was transferred once a week.

$T$. perometabolis THI 024 newly received from the American Type Culture Collection was similar to strain THI 022 in its morphological and physiological characteristics, its ubiquinone, its cellular fatty acid composition, and the $\mathrm{G}+\mathrm{C}$ content of its deoxyribonucleic acid. Therefore, we present data for strain THI 024 below.

Bacterial names which are not on the Approved Lists of Bacterial Names (11) or have not been validly 
TABLE 1. Bacterial strains studied

\begin{tabular}{|c|c|c|c|c|}
\hline Group $^{a}$ & Designation & Received as: ${ }^{b}$ & Source & Remarks \\
\hline \multirow[t]{4}{*}{$\mathbf{I}$} & THI 022 & T. perometabolis ATCC 27793 & & Received on 6 April 1978 \\
\hline & THI 024 & T. perometabolis ATCC 27793 & & Received on 29 August 1980 \\
\hline & THI $041^{\mathrm{T}}$ & $\begin{array}{l}\text { Thiobacillus sp. strain } \mathrm{A}^{\mathrm{T}}(= \\
\left.\quad \text { ATCC } 25364^{\mathrm{T}}\right)\end{array}$ & & \\
\hline & THI $031^{\mathrm{T}}$ & $T$. novellus IAM $12100^{\mathrm{T}}$ & ATCC $8093^{\mathrm{T}}$ & \\
\hline II & THI $023^{\mathrm{T}}$ & T. perometabolis IAM $12132^{\mathrm{T}}$ & ATCC $23370^{\mathrm{T}}$ & \\
\hline
\end{tabular}

${ }^{a}$ See reference 5 .

${ }^{b}$ ATCC, American Type Culture Collection, Rockville, Md.; IAM, Institute of Applied Microbiology, University of Tokyo, Tokyo, Japan.

published since 1 January 1980 are enclosed in quotation marks.

Identification methods. The morphological characteristics of most strains were examined by using cells grown in BY medium; $T$. perometabolis $\mathrm{THI} 023^{\mathrm{T}}$ was grown in SM basal salts-thiosulfate-yeast extract medium. BY medium contained $5 \mathrm{~g}$ of meat extract (Kyokuto, Tokyo, Japan), $5 \mathrm{~g}$ of peptone (Kyokuto), 5 $\mathrm{g}$ of yeast extract (Kyokuto), $2.5 \mathrm{~g}$ of $\mathrm{NaCl}, 0.1 \mathrm{~g}$ of $\mathrm{K}_{2} \mathrm{HPO}_{4}, 0.05 \mathrm{~g}$ of $\mathrm{MgSO}_{4} \cdot 7 \mathrm{H}_{2} \mathrm{O}$, and $1,000 \mathrm{ml}$ of tap water; the $\mathrm{pH}$ of this medium was 7.2 (3).

Motility was tested by using cultures grown in liquid BY medium or SM basal salts medium supplemented with thiosulfate with or without yeast extract at $30^{\circ} \mathrm{C}$. Flagellation and cell size were confirmed by using cells cultured overnight on agar slants after negative staining with $1 \%(\mathrm{wt} / \mathrm{vol})$ phosphotungstic acid and a model JEOL 200CX transmission electron microscope at 100 $\mathrm{kV}$.

Physiological characteristics were examined in SM basal salts medium supplemented with adequate substrates by using methods described previously (3). SM basal salts medium contained $1.5 \mathrm{~g}$ of $\mathrm{KH}_{2} \mathrm{PO}_{4}, 4.5 \mathrm{~g}$ of $\mathrm{Na}_{2} \mathrm{HPO}_{4}, 0.1 \mathrm{~g}$ of $\mathrm{MgSO}_{4} \cdot 7 \mathrm{H}_{2} \mathrm{O}, 0.3 \mathrm{~g}$ of $\mathrm{NH}_{4} \mathrm{Cl}, 5$ $\mathrm{ml}$ of a trace metal solution (17), and $1,000 \mathrm{ml}$ of deionized water; the $\mathrm{pH}$ of this medium was adjusted to 7.5 (5). SM basal salts medium $(\mathrm{pH} \mathrm{6.0)}$ was used for the experiments with $T$. perometabolis $\mathrm{THI} 023^{\mathrm{T}}$. One loopful of cells was suspended in $10 \mathrm{ml}$ of sterilized water, and this suspension was used as the inoculum (final concentration, 1\%) in fresh liquid medium.

The ability to assimilate inorganic sulfur compounds was examined in liquid SM basal salts medium containing sodium thiosulfate $(5 \mathrm{~g} /$ liter $)$, elemental sulfur ( $10 \mathrm{~g} /$ /iter $)$, or potassium tetrathionate ( $3 \mathrm{~g} /$ liter). These substrates were autoclaved separately and added to the basal salts medium. Powdered sulfur was sterilized by intermittent steaming. Assimilation was determined on the basis of growth, changes in the $\mathrm{pH}$ of the media, decreases in the amounts of substrates, and resultant formation of sulfate during successive transfers in media of the same composition. Utilization of potassium thiocyanate $(100 \mathrm{mg} / \mathrm{liter})$ was examined in the medium described previously (3).

Assimilation of organic compounds was examined heterotrophically by using agar plates, as described previously (3). In addition, the assimilation test for $T$. perometabolis THI $023^{\mathrm{T}}$ was carried out by using heterotrophic media and mixotrophic media which were supplemented with $5 \%(\mathrm{wt} / \mathrm{vol})$ sodium thiosulfate. Assimilation ability was determined after 2 weeks of incubation by comparing the sizes of the colonies on a test plate containing the substrate with the sizes of colonies on a control plate which contained only the basal salts medium.

Analytical methods. Thiosulfate and tetrathionate were analyzed by the method of Kelly et al. (6). Sulfate was determined gravimetrically after the addition of a $5 \%(\mathrm{wt} / \mathrm{vol}) \mathrm{BaCl}_{2} \cdot 2 \mathrm{H}_{2} \mathrm{O}$ solution in $0.1 \mathrm{~N}$ $\mathrm{HCl}$. Potassium tetrathionate was prepared as described by Trudinger (15). The other chemicals used were available commercially.

\section{RESULTS}

Morphological and physiological characteristics. Table 2 shows the morphological and physiological characteristics of Thiobacillus sp. strain $\mathrm{A} 2^{\mathrm{T}}, T$. perometabolis $\mathrm{THI} 024, T$. novellus THI $031^{\mathrm{T}}$, and T. perometabolis THI $023^{\mathrm{T}}$.

Thiobacillus sp. strain $\mathrm{A} 2^{\mathrm{T}}$ and $T$. perometabolis THI 024 were motile by tufts of polar flagella, as shown in Fig. 1. T. perometabolis THI $023^{\mathrm{T}}$ had a single polar flagellum (Fig. 1) (8). Motility was not observed in $T$. novellus THI $031^{\mathrm{T}}(3,13)$.

Thiobacillus sp. strain $\mathrm{A}^{\mathrm{T}}$ and $T$. perometabolis THI 024 could grow anaerobically in the presence of nitrate in SM basal salts-glucose medium and evolved gas actively. However, denitrification was not observed in thiosulfate medium supplemented with nitrate. $T$. novellus THI $031^{\mathrm{T}}$ and $T$. perometabolis THI $023^{\mathrm{T}}$ were obligate aerobes.

Both strains of $T$. perometabolis (THI $023^{\mathrm{T}}$ and THI 024) were able to grow in a liquid medium supplemented with thiosulfate (5); we observed regular cell yields of ca. 30 to $40 \mu \mathrm{g}$ of protein per ml and an optical density at $660 \mathrm{~nm}$ of ca. 0.1 during successive transfers in liquid medium supplemented with sodium thiosulfate ( $5 \mathrm{~g} /$ liter). This growth was accompanied by decreases in the $\mathrm{pH}$ of the medium. The cell yields in this medium corresponded to the yields obtained with other facultatively chemolithotrophic Thiobacillus strains, such as Thiobacillus sp. strain $\mathrm{A}^{\mathrm{T}}, T$. novellus $\mathrm{THI} 031^{\mathrm{T}}$, Thiobacillus intermedius THI 101, and "Thiobacillus deli- 
TABLE 2. Characteristics of Thiobacillus sp. strain $\mathrm{A} 2^{\mathrm{T}}, T$. perometabolis $\mathrm{THI} 024$, T. novellus $\mathrm{THI} 031^{\mathrm{T}}$, and $T$. perometabolis THI $023^{\mathrm{T}}$

\begin{tabular}{|c|c|c|c|c|}
\hline Character & $\begin{array}{l}\text { Thiobacillus } \\
\text { sp. strain } \mathrm{A} 2^{\mathrm{T}}\end{array}$ & $\begin{array}{l}\text { T. perometabolis } \\
\text { THI } 024\end{array}$ & $\begin{array}{l}\text { T. novellus } \\
\text { THI } 031^{\mathrm{T} a}\end{array}$ & $\begin{array}{l}\text { T. perometabolis } \\
\text { THI } 023^{\mathrm{T}}\end{array}$ \\
\hline Cell morphology & Rod & Rod & Rod & Rod \\
\hline Cell width & $0.6-0.7 \mu \mathrm{m}$ & $0.5-0.7 \mu \mathrm{m}$ & $0.7-0.8 \mu \mathrm{m}$ & $0.4-0.5 \mu \mathrm{m}$ \\
\hline Cell length & $1.0-1.3 \mu \mathrm{m}$ & $1.0-1.5 \mu \mathrm{m}$ & $1.1-1.5 \mu \mathrm{m}$ & $1.1-1.7 \mu \mathrm{m}$ \\
\hline Motility & + & + & - & + \\
\hline Flagellation & Tuft & Tuft & - & Polar \\
\hline Spore formation & - & - & - & - \\
\hline Gram reaction & - & - & - & - \\
\hline Acid-alcohol-fast & - & - & - & - \\
\hline Nitrate reduction ${ }^{b}$ & + & + & - & - \\
\hline Denitrification $^{b}$ & + & + & - & - \\
\hline Denitrification $^{c}$ & - & - & - & - \\
\hline \multicolumn{5}{|l|}{ Assimilation of: } \\
\hline Elemental sulfur & $\mathrm{w}^{d}$ & $\mathrm{w}$ & - & + \\
\hline Thiocyanate & - & - & - & - \\
\hline Thiosulfate & + & + & + & + \\
\hline Tetrathionate & - & - & + & + \\
\hline \multicolumn{5}{|l|}{ Nitrogen source $^{e}$} \\
\hline $\mathrm{KNO}_{3}$ & + & + & + & + \\
\hline $\mathrm{NH}_{4} \mathrm{Cl}$ & + & + & + & + \\
\hline Urea & - & - & + & + \\
\hline Glutamate & + & + & + & + \\
\hline Aspartate & + & + & - & + \\
\hline \multicolumn{5}{|l|}{ Temperature for growth ${ }^{f}$} \\
\hline Optimum & $30-37^{\circ} \mathrm{C}$ & $30-37^{\circ} \mathrm{C}$ & $25-30^{\circ} \mathrm{C}$ & $35-37^{\circ} \mathrm{C}$ \\
\hline Maximum & $40^{\circ} \mathrm{C}$ & $42^{\circ} \mathrm{C}$ & $37^{\circ} \mathrm{C}$ & $42^{\circ} \mathrm{C}$ \\
\hline Minimum & $17^{\circ} \mathrm{C}$ & $15^{\circ} \mathrm{C}$ & $10^{\circ} \mathrm{C}$ & $15^{\circ} \mathrm{C}$ \\
\hline \multicolumn{5}{|l|}{ Initial $\mathrm{pH}$ for growth ${ }^{f}$} \\
\hline Optimum & $7.5-8.0$ & $7.5-8.0$ & 7.0 & $5.5-6.0$ \\
\hline Maximum & 9.5 & 9.5 & 7.5 & 7.0 \\
\hline Minimum & 6.5 & 6.5 & 6.0 & 5.0 \\
\hline \multicolumn{5}{|l|}{ Initial $\mathrm{pH}$ for growth ${ }^{c}$} \\
\hline Optimum & $8.0-9.0$ & $7.5-8.0$ & $7.0-7.4$ & $5.5-6.0$ \\
\hline Maximum & 9.5 & 9.5 & 9.0 & 7.5 \\
\hline Minimum & 6.5 & 6.5 & 5.7 & 5.0 \\
\hline Hydrolysis of gelatin & - & - & - & - \\
\hline Nutritional requirement & - & - & Biotin & $\begin{array}{l}\text { Reduced inorganic } \\
\text { sulfur compound }\end{array}$ \\
\hline $\begin{array}{l}\mathrm{G}+\mathrm{C} \text { content of deoxyribonucleic } \\
\text { acid }\end{array}$ & $67.0 \mathrm{~mol} \%$ & $67.1-67.8 \mathrm{~mol} \%$ & $67.3 \mathrm{~mol} \%$ & $65.0 \mathrm{~mol} \%$ \\
\hline Ubiquinone system $^{g}$ & Q-10 & Q-10 & Q-10 & Q-8 \\
\hline \multicolumn{5}{|l|}{ Major cellular fatty acids ${ }^{h}$} \\
\hline Non-hydroxylated & $18: 1+19 c y c$ & $18: 1+19$ cyc & $18: 1+19$ cyc & $\begin{array}{c}16: 0,16: 1+17 \mathrm{cyc} \\
18: 1+19 \mathrm{cyc}\end{array}$ \\
\hline Hydroxylated & 3-OH 10:0 & $3-\mathrm{OH} \mathrm{10:0}$ & $\mathrm{ND}^{i}$ & $3-\mathrm{OH} 10: 0,3-\mathrm{OH} 12: 0$ \\
\hline
\end{tabular}

${ }^{a}$ From reference 3 .

${ }^{b}$ Determined in SM basal salts medium containing $5 \%(\mathrm{wt} / \mathrm{vol})$ glucose, except for T. perometabolis $\mathrm{THI} 023^{\mathrm{T}}$, which was grown in $\mathrm{SM}$ basal salts medium containing $5 \%$ (wt/vol) $\mathrm{Na}_{2} \mathrm{~S}_{2} \mathrm{O}_{3} \cdot 5 \mathrm{H}_{2} \mathrm{O}$ and $0.4 \%$ (wt/vol) malate.

${ }^{c}$ Determined in $\mathrm{SM}$ basal salts medium containing $5 \%$ (wt/vol) $\mathrm{Na}_{2} \mathrm{~S}_{2} \mathrm{O}_{3} \cdot 5 \mathrm{H}_{2} \mathrm{O}$.

${ }^{d} \mathrm{~W}$, Weakly positive.

${ }^{e}$ Determined in SM basal salts medium containing $5 \%$ (wt/vol) $\mathrm{Na}_{2} \mathrm{~S}_{2} \mathrm{O}_{3} \cdot 5 \mathrm{H}_{2} \mathrm{O}$ and $\mathrm{SM}$ basal salts medium containing $5 \%(\mathrm{wt} / \mathrm{vol})$ glucose, except for $T$. perometabolis $\mathrm{THI} 023^{\mathrm{T}}$, which was grown in $\mathrm{SM}$ basal salts medium containing $5 \%$ (wt/vol) $\mathrm{Na}_{2} \mathrm{~S}_{2} \mathrm{O}_{3} \cdot 5 \mathrm{H}_{2} \mathrm{O}$ and $\mathrm{SM}$ basal salts medium containing $5 \%$ (wt/vol) $\mathrm{Na}_{2} \mathrm{~S}_{2} \mathrm{O}_{3}$. $5 \mathrm{H}_{2} \mathrm{O}$ and $0.4 \%(\mathrm{wt} / \mathrm{vol})$ malate.

${ }^{f}$ Determined in BY medium, except for T. perometabolis THI $023^{\mathrm{T}}$, which was grown in SM basal salts medium containing $5 \%(\mathrm{wt} / \mathrm{vol}) \mathrm{Na}_{2} \mathrm{~S}_{2} \mathrm{O}_{3} \cdot 5 \mathrm{H}_{2} \mathrm{O}$ and $5 \%(\mathrm{wt} / \mathrm{vol})$ yeast extract.

${ }^{8}$ Q-10, Ubiquinone 10 ; Q-8, ubiquinone 8 .

${ }^{h} 18: 1$, Octadecenoic acid; 19 cyc, cyclopropane acid of $C_{19} ; 16: 0$, hexadecanoic acid; $16: 1$, hexadecenoic acid; 17 cyc, cyclopropane acid of $\mathrm{C}_{17} ; 3-\mathrm{OH}$ 10:0, 3-hydroxydecanoic acid; 3-OH 12:0, 3-hydroxydodecanoic acid.

${ }^{i}$ ND, Not detected. 


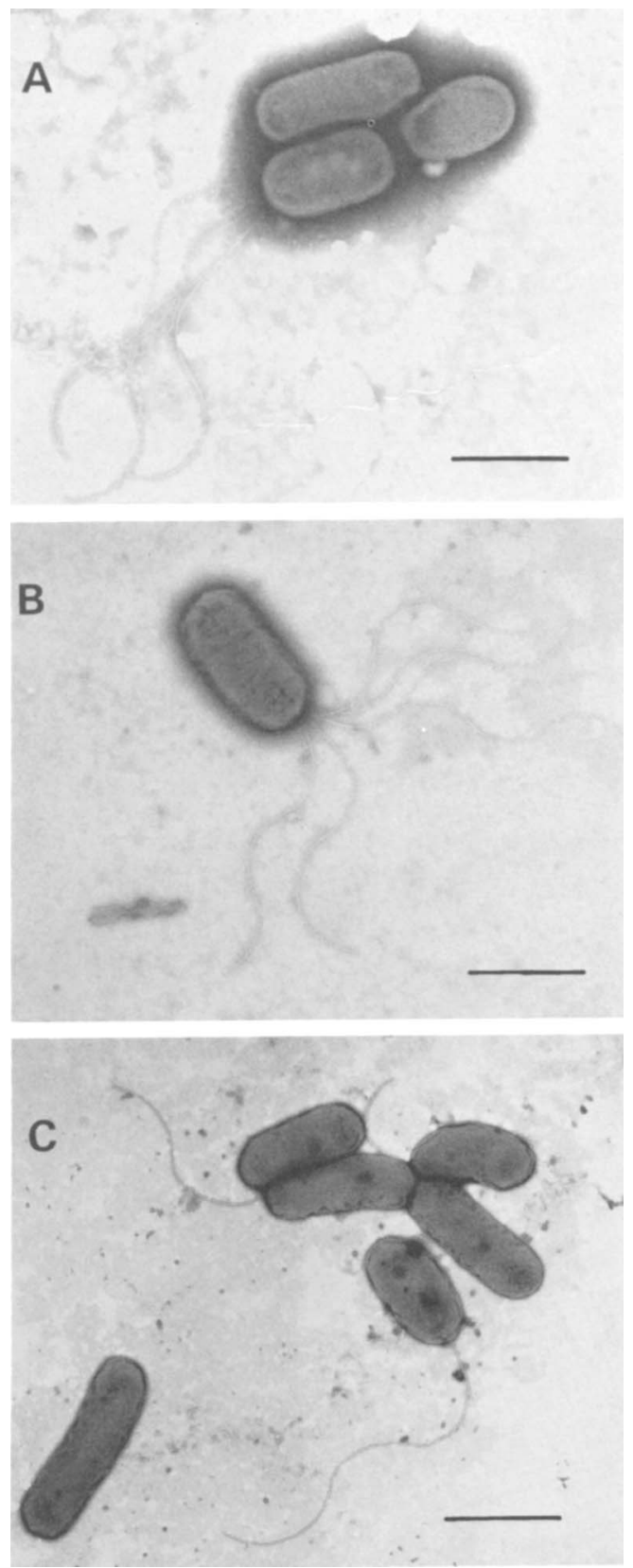

FIG. 1. Electron micrographs of Thiobacillus $\mathrm{sp}$. strain $\mathrm{A} 2{ }^{\mathrm{T}}(\mathrm{A}), T$. perometabolis $\mathrm{THI} 024(\mathrm{~B})$, and $T$. perometabolis THI $023^{\mathrm{T}}(\mathrm{C})$, showing flagellum arrangement. The preparations were stained with phosphotungstic acid. Bar $=1 \mu \mathrm{m}$.

catus" THI 091, as determined in our laboratory. Thiobacillus sp. strain $\mathrm{A}^{\mathrm{T}}$ and $T$. novellus THI $031^{\mathrm{T}}$ utilized thiosulfate for autotrophic growth and decreased the $\mathrm{pH}$ of the medium (13, 14).

Thiobacillus sp. strain $\mathrm{A} 2^{\mathrm{T}}$ and $T$. perometa- bolis THI 024 were able to oxidize elemental sulfur weakly, as determined by changes in the $\mathrm{pH}$ of the medium; during three transfers the $\mathrm{pH}$ decreased by about $0.5 \mathrm{u}$. On the other hand, the $\mathrm{pH}$ of a medium inoculated with $T$. novellus $\mathrm{THI}$ $031^{\mathrm{T}}$, which did not utilize elemental sulfur, hardly changed; a similar result was observed with a non-inoculated system after 3 weeks of incubation.

Thiobacillus sp. strain $\mathrm{A}^{\mathrm{T}}$ and $T$. perometabolis $\mathrm{THI} 024$ did not assimilate tetrathionate or thiocyanate. $T$. novellus THI $031^{\mathrm{T}}$ used tetrathionate for autotrophic growth (the $\mathrm{pH}$ of the medium decreased) and did not use elemental sulfur, as described above (3). T. perometabolis THI $023^{\mathrm{T}}$ oxidized elemental sulfur and tetrathionate in an autotrophic liquid medium, and the $\mathrm{pH}$ of the medium decreased after 1 week of incubation.

Thiobacillus sp. strain $\mathrm{A} 2^{\mathrm{T}}$ and $T$. perometabolis THI 024 used potassium nitrate and ammonium chloride as nitrogen sources in both SM basal salts-thiosulfate medium and SM basal salts-glucose medium, but they did not use urea. Potassium nitrate, ammonium chloride, and urea were used by $T$. novellus THI $031^{\mathrm{T}}$ in SM basal salts-thiosulfate and SM basal salts-glucose media (3) and by $T$. perometabolis $\mathrm{THI} 023^{\mathrm{T}}$ in $\mathrm{SM}$ basal salts-thiosulfate and SM basal salts-thiosulfate-malate media.

Thiobacillus $\mathrm{sp}$. strain $\mathrm{A} 2^{\mathrm{T}}$ and $T$. perometabolis THI 024 grew well at $\mathrm{pH} 7.5$ to 8.0 in $\mathrm{BY}$ medium, whereas $T$. novellus THI $031^{\mathrm{T}}$ grew well at $\mathrm{pH} 7.0$ (3). Slightly acidic conditions $(\mathrm{pH}$ 5.5 to 6.0 in SM basal salts-thiosulfate or SM basal salts-thiosulfate-yeast extract medium) produced the best growth of $T$. perometabolis THI $023^{\mathrm{T}}$.

Thiobacillus sp. strain $\mathrm{A} 2^{\mathrm{T}}$ and $T$. perometabolis THI 024 did not require any growth factor, whereas $T$. novellus $\mathrm{THI} 031^{\mathrm{T}}$ required biotin ( 3 , 9). T. perometabolis THI $023^{\mathrm{T}}$ was able to grow in a defined medium supplemented with a single carbon source (Table 3 ) but only after a long lag period; the presence of thiosulfate with the carbon source markedly shortened the lag time. Thus, this organism seemed to require reduced sulfur compounds for optimal growth.

Assimilation of organic compounds. Thiobacillus sp. strain $\mathrm{A}^{\mathrm{T}}$ and $T$. perometabolis $\mathrm{THI} 024$ assimilated amino acids, carbohydrates, organic acids, aromatic compounds, and alcohols, as shown in Table 3. T. novellus THI $031^{\mathrm{T}}$ assimilated a more limited number of carbon compounds than Thiobacillus sp. strain $\mathrm{A}^{\mathrm{T}}$ and $T$. perometabolis THI 024 (3). The generation times of Thiobacillus sp. strain $\mathrm{A} 2^{\mathrm{T}}$ and $T$. perometabolis THI 024 were 2 and $2.2 \mathrm{~h}$, respectively, in liquid SM basal salts medium supplemented with $20 \mathrm{mM}$ glutamate. The generation time of $T$. 
TABLE 3. Utilization of organic compounds by Thiobacillus sp. strain $\mathrm{A} 2^{\mathrm{T}}, T$. perometabolis $\mathrm{THI}$ 024, $T$. novellus THI $031^{\mathrm{T}}$, and $T$. perometabolis $\mathrm{THI}$

\begin{tabular}{|c|c|c|c|c|}
\hline Substrate & $\begin{array}{c}\text { Thioba- } \\
\text { cillus sp. } \\
\text { strain } \\
\mathrm{A} 2^{a}\end{array}$ & $\begin{array}{c}\text { T. perome- } \\
\text { tabolis } \\
\text { THI } 024^{a}\end{array}$ & \begin{tabular}{|c|} 
T. no- \\
vellus \\
THI \\
$031^{\mathrm{Ta}}$
\end{tabular} & $\begin{array}{l}T \text {. pero- } \\
\text { metabolis } \\
\text { THI } 023^{\text {Th }}\end{array}$ \\
\hline L-Alanine & + & + & + & $+(+)$ \\
\hline L-Serine & + & + & $\mathrm{w}^{c}$ & $-(+)$ \\
\hline L-Leucine & + & + & - & $-(-)$ \\
\hline L-Isoleucine & + & + & - & $-(-)$ \\
\hline L-Aspartate & + & + & - & $w(+)$ \\
\hline L-Glutamate & + & + & + & $+(+)$ \\
\hline L-Proline & + & + & + & $-(-)$ \\
\hline L-Histidine & + & + & + & $-(w)$ \\
\hline L-Phenylalanine & + & + & $w$ & $-(-)$ \\
\hline L-Tryptophan & - & - & - & $-(-)$ \\
\hline L-Cysteine & - & - & - & $-(-)$ \\
\hline L-Arabinose & + & + & + & $-(-)$ \\
\hline D-Ribose & + & + & + & $-(-)$ \\
\hline D-Glucose & + & + & + & $-(w)$ \\
\hline D-Galactose & + & + & + & $-(-)$ \\
\hline Fructose & + & + & + & $-(-)$ \\
\hline Lactose & - & - & - & $-(-)$ \\
\hline Maltose & + & + & w & $-(-)$ \\
\hline Sucrose & + & + & w & $-(-)$ \\
\hline Gluconate & + & + & + & $-(w)$ \\
\hline Glycerol & + & + & + & $-(-)$ \\
\hline Mannitol & + & + & + & $-(-)$ \\
\hline Cellobiose & - & $\rightarrow$ & - & $-(-)$ \\
\hline Formate & + & + & + & $-(-)$ \\
\hline Acetate & + & + & + & $-(-)$ \\
\hline Propionate & + & + & w & $-(-)$ \\
\hline$n$-Butyrate & + & + & - & $-(-)$ \\
\hline Lactate & + & + & + & $-(-)$ \\
\hline Pyruvate & + & + & + & $-(-)$ \\
\hline L-Malate & + & + & + & $w(+)$ \\
\hline Succinate & + & + & + & $w(+)$ \\
\hline Citrate & - & - & + & $w(+)$ \\
\hline$\alpha$-Ketoglutarate & + & + & w & $-(+)$ \\
\hline Glutarate & + & + & w & $-(-)$ \\
\hline Oxalate & - & - & + & $-(-)$ \\
\hline Adipate & + & + & - & $-(-)$ \\
\hline Pimerate & - & - & - & $-(-)$ \\
\hline Methanol & w & w & w & $-(-)$ \\
\hline Ethanol & + & + & + & $-(w)$ \\
\hline$n$-Propanol & + & + & + & $-(-)$ \\
\hline$n$-Butanol & + & + & w & $-(-)$ \\
\hline Cyclohexanol & - & - & - & $-(-)$ \\
\hline Benzoate & + & + & - & $-(-)$ \\
\hline$o$-Hydroxybenzoate & - & - & - & $-(-)$ \\
\hline$m$-Hydroxybenzoate & + & + & - & $-(-)$ \\
\hline$p$-Hydroxybenzoate & + & + & - & $-(-)$ \\
\hline$p$-Aminobenzoate & - & - & - & $-(-)$ \\
\hline DL-Mandelate & - & - & - & $-(-)$ \\
\hline
\end{tabular}

\footnotetext{
${ }^{a}$ Determined on SM basal salts medium.

${ }^{b}$ Determined on SM basal salts medium and on SM basal salts medium containing $5 \%$ (wt/vol) $\mathrm{Na}_{2} \mathrm{~S}_{2} \mathrm{O}_{3}$. $5 \mathrm{H}_{2} \mathrm{O}$ (results in parentheses).

${ }^{c} \mathrm{w}$, Weakly positive.
}

novellus THI $031^{\mathrm{T}}$ was 10 times longer (3) than the generation times of Thiobacillus sp. strain $\mathrm{A} 2^{\mathrm{T}}$ and $T$. perometabolis $\mathrm{THI} 024$ in the same medium.

After a prolonged lag phase (about 2 weeks), T. perometabolis THI $023^{\mathrm{T}}$ grew slowly in heterotrophic media containing alanine, glutamate, malate, citrate, succinate, or aspartate. This organism tended to form floc in liquid media containing these compounds. The maximum cell yields (expressed as optical densities at $660 \mathrm{~nm}$ ) were 0.6 and 0.2 in SM basal salts medium containing $20 \mathrm{mM}$ glutamate and SM basal salts medium containing $20 \mathrm{mM}$ malate, respectively. The lag phase was shortened by adding thiosulfate to the media, as mentioned above. Furthermore, $T$. perometabolis THI $023^{\mathrm{T}}$ grew in mixotrophic medium containing $\alpha$-ketoglutarate, serine, or histidine. Weak growth, as determined by colony formation on plates and by optical density in liquid media, was observed in a mixotrophic medium containing glucose or gluconate.

Description of Thiobacillus rapidicrescens Katayama-Fujimura and Kuraishi sp. nov. In their morphological, physiological, and chemotaxonomic characteristics, Thiobacillus sp. strain $\mathrm{A} 2^{\mathrm{T}}$ and $T$. perometabolis $\mathrm{THI} 024$ were quite similar to each other and distinct from the known Thiobacillus species. We propose a new species, Thiobacillus rapidicrescens (ra.pi.di.cres'cens. L. adj. rapidus rapid; L. part. adj. crescens growing; M. L. part. adj. rapidicrescens rapid growing), for Thiobacillus sp. strain $\mathrm{A}^{\mathrm{T}}$ and $T$. perometabolis THI 024; the description of this species is based on the characteristics of the type strain, strain A2 (= THI 041).

(i) Cell morphology. Rod-shaped cells (average dimensions, 0.4 to $0.5 \mu \mathrm{m}$ wide by 1.1 to $1.7 \mu \mathrm{m}$ long) with rounded ends. Cells occur singly or in pairs. Motile by means of tufts of polar flagella. Nonsporeforming. Gram negative. Not acid-alcohol-fast.

(ii) Colonial appearance. Colonies on BY medium are circular, wrinkled with raised centers, lobate, spreading, brownish yellow, opaque, and about 3 to $4 \mathrm{~mm}$ in diameter after 2 days of incubation. Colonies on thiosulfate medium are circular, convex, smooth, entire, creamy white, and opaque, developing a brown center with age; these colonies are about $2 \mathrm{~mm}$ in diameter after 1 week of incubation.

(iii) Biochemical and physiological properties. $T$. rapidicrescens is facultatively anaerobic and in heterotrophic medium supplemented with nitrate grows anaerobically and evolves gas actively.

This species is a facultative chemolithotroph. Thiosulfate is utilized for growth as an energy source. Elemental sulfur is oxidized slowly. Tet- 
rathionate or thiocyanate does not support growth.

Potassium nitrate and ammonium chloride are utilized as nitrogen sources, but urea is not. Glutamate and aspartate are utilized as both nitrogen and carbon sources.

Alanine, serine, leucine, isoleucine, aspartate, glutamate, proline, histidine, phenylalanine, arabinose, ribose, glucose, galactose, fructose, maltose, sucrose, gluconate, glycerol, mannitol, formate, acetate, propionate, $n$-butyrate, lactate, pyruvate, malate, succinate, $\alpha$-ketoglutarate, glutarate, adipate, ethanol, $n$-propanol, $n$ butanol, benzoate, $m$-hydroxybenzoate, and $p$ hydroxybenzoate are utilized as carbon sources. Heterotrophic growth is not stimulated by the presence of thiosulfate.

Growth occurs at 17 to $40^{\circ} \mathrm{C}$, but not at 10 or $42^{\circ} \mathrm{C}$; optimum growth occurs between 30 and $37^{\circ} \mathrm{C}$.

Growth occurs at $\mathrm{pH} 6.5$ to 9.5 , and optimum growth occurs at $\mathrm{pH} 7.5$ to 8.0 in $\mathrm{BY}$ medium and at $\mathrm{pH} 8.0$ to 9.0 in SM basal salts-thiosulfate medium.

Gelatin is not liquefied.

Growth factor is not required.

$\mathrm{G}+\mathrm{C}$ content: $67.0 \mathrm{~mol} \%$.

Ubiquinone system: ubiquinone 10 .

This organism has octadecenoic acid plus cy. clopropane acid of $\mathrm{C}_{19}$ as major non-hydroxylated cellular fatty acids and 3-hydroxydecanoic acid as a hydroxylated fatty acid.

Isolated from soil (14).

The type strain of this organism is strain THI 041; this strain has been deposited with the American Type Culture Collection under accession number ATCC 25364. An additional strain, $T$. rapidicrescens THI 024 , has been deposited with the American Type Culture Collection under accession number ATCC 27793 (1).

\section{DISCUSSION}

T. perometabolis has been regarded as a nonautotrophic organism on the basis of its inability to grow in a thiosulfate-mineral salts liquid medium when it is inoculated from colonies on plates containing medium of the same composition $(8$, 16). In our study, strains THI $023^{\mathrm{T}}$ and THI 024 readily initiated growth in a liquid thiosulfate medium when they were transferred from cultures derived from successive inoculations on agar slants of the same composition, as well as agar media for mixotrophic growth. Furthermore, adequate growth was observed after transfer into a thiosulfate-mineral salts liquid medium. Therefore, we considered this organism to be able to grow autotrophically. $T$. perometabolis $\mathrm{THI} 023^{\mathrm{T}}$ grew in heterotrophic media containing yeast extract or Casamino Acids (8) and single carbon compounds, such as
TABLE 4. Characteristics that differentiate $T$. rapidicrescens and $T$. novellus

\begin{tabular}{l|c|c}
\hline \multicolumn{1}{c|}{ Character } & $\begin{array}{c}\text { T. rapidi } \\
\text { crescens }\end{array}$ & $\begin{array}{c}T . \\
\text { novellus }\end{array}$ \\
\hline Motility & + & - \\
Nitrate reduction in & + & - \\
$\quad$ heterotrophic medium & + & - \\
$\begin{array}{l}\text { Denitrification in heterotrophic } \\
\text { medium }\end{array}$ & - & + \\
Assimilation of tetrathionate & $7.5-8.0$ & 7.0 \\
Initial pH of BY medium for & & \\
$\quad$ optimum growth & $30-37^{\circ} \mathrm{C}$ & $25-30^{\circ} \mathrm{C}$ \\
Optimum temperature for growth & $1 \mathrm{~h}$ & $3 \mathrm{~h}$ \\
Generation time in BY medium & - & $\mathrm{Biotin}$ \\
Nutritional requirement & + & - \\
3-OH 10:0 fatty acid &
\end{tabular}

${ }^{a}$ 3-OH 10:0, 3-Hydroxydecanoic acid.

malate, citrate, succinate, alanine, or aspartate. Growth in the media containing single carbon compounds required long lag periods. On the basis of these results, this organism was considered to be a facultative chemolithotroph, contrary to the original description (8). The name $T$. perometabolis appeared on the Approved Lists of Bacterial Names (11). Therefore, emendation of $T$. perometabolis is needed for exact identification of this species (4).

T. perometabolis $\mathrm{THI} 024$ was able to grow on media containing a wide range of organic compounds in addition to thiosulfate, and this strain was also considered a facultative chemolithotroph. The pattern of assimilation of amino acids by $T$. perometabolis THI 024 was more versatile than the pattern described by Myers and Miller (10), who examined amino acids as both nitrogen and carbon sources.

Thiobacillus sp. strain $\mathrm{A} 2^{\mathrm{T}}$ was isolated from an anaerobic enrichment culture of "Thiobacillus denitrificans" and has been considered a strain or biovar of $T$. novellus (14). Characteristics useful for differentiating Thiobacillus sp. strain $\mathrm{A}^{\mathrm{T}}$ and $T$. novellus $\mathrm{THI} 031^{\mathrm{T}}$ have been identified through our taxonomic studies of the genus Thiobacillus $(3,5)$. As a result, we have concluded that these two organisms belong to different taxa. Table 4 shows the characteristics that are useful for identifying $T$. rapidicrescens.

\section{ACKNOWLEDGMENTS}

We thank K. Komagata, J. Sugiyama, and K. Uchida, Institute of Applied Microbiology, University of Tokyo, Tokyo, Japan, for useful discussions. We also thank A. Hirata, Institute of Applied Microbiology, University of Tokyo, for technical advice on electron microscopy.

\section{LITERATURE CITED}

1. Gherna, R. L., and P. Pienta. 1982. Bacteria, p. 57-242. In H. D. Hatt, M. J. Gantt, and J. Pipar (ed.), The American Type Culture Collection catalogue of strains I, 15th ed., American Type Culture Collection, Rockville, Md. 
2. Gottschal, J. C., A. Pol, and J. G. Kuenen. 1981. Metabolic flexibility of Thiobacillus A2 during substrate transitions in the chemostat. Arch. Microbiol. 129:23-28.

3. Katayama-Fujimura, Y., and H. Kuraishi. 1980. Characteristics of Thiobacillus novellus and its thiosulfate oxidation. J. Gen. Appl. Microbiol. 26:357-367.

4. Katayama-Fujimura, Y., and H. Kuraishi. 1983. Emenda tion of Thiobacillus perometabolis London and Rittenberg 1967. Int. J. Syst. Bacteriol. 33:650-651.

5. Katayama-Fujimura, Y., N. Tsuzaki, and H. Kuraishi. 1982. Ubiquinone, fatty acid and DNA base composition determination as a guide to the taxonomy of the genus Thiobacillus. J. Gen. Microbiol. 128:1599-1611.

6. Kelly, D. P., L. A. Chambers, and P. A. Trudinger. 1969. Cyanolysis and spectrophotometric estimation of trithionate in mixture with thiosulfate and tetrathionate. Anal. Chem. 41:898-901.

7. Kula, T. J., M. I. H. Aleem, and D. F. Wilson. 1982. Oxidation-reduction potentials of respiratory chain components in Thiobacillus A2. Biochim. Biophys. Acta 680:142-151.

8. London, J., and S. C. Rittenberg. 1967. Thiobacillus perometabolis nov. sp., a non-autotrophic thiobacillus. Arch. Mikrobiol. 59:218-225.

9. Matin, A., F. J. Kahan, and R. H. Leefeldt. 1980. Growth factor requirement of Thiobacillus novellus. Arch. Microbiol. 124:91-95.
10. Myers, P. S., and W. N. Millar. 1975. Nonautotrophic Thiobacillus in acid mine water. Appl. Microbiol. 30:884886.

11. Skerman, V. B. D., V. McGowan, and P. H. A. Sneath (ed.). 1980. Approved lists of bacterial names. Int. J. Syst. Bacteriol. 30:225-420.

12. Smith, A. L., D. P. Kelly, and A. P. Wood. 1980. Metabolism of Thiobacillus A2 grown under autotrophic, mixotrophic and heterotrophic conditions in chemostat culture. J. Gen. Microbiol. 121:127-138.

13. Starkey, R. L. 1935. Isolation of some bacteria which oxidize thiosulfate. Soil Sci. 39:197-219.

14. Taylor, B. F., and D. S. Hoare. 1969. New facultative Thiobacillus and a reevaluation of the heterotrophic potential of Thiobacillus novellus. J. Bacteriol. 100:487-497.

15. Trudinger, P. A. 1961. Thiosulfate oxidation and cytochromes in Thiobacillus X. II. Thiosulfate-oxidizing enzyme. Biochem. J. 78:680-686.

16. Vishniac, W. V. 1974. Genus Thiobacillus, p. 456-461. In R. E. Buchanan and N. E. Gibbons (ed.), Bergey's manual of determinative bacteriology, 8th ed. The Williams \& Wilkins Co., Baltimore.

17. Vishniac, W., and M. Santer. 1957. The thiobacilli. Bacteriol. Rev. 21:195-213.

18. Wood, A. P., and D. P. Kelly. 1981. Mixotrophic growth of Thiobacillus A2 in chemostat culture on formate and glucose. J. Gen. Microbiol. 125:55-62. 